\title{
Electrocuted! Amphibian deaths caused by electric discharge
}

\author{
R. A. Regnet ${ }^{a *}$ and D. Loebmann ${ }^{a}$
}

aPrograma de Pós-graduação em Biologia de Ambientes Aquáticos Continentais, Laboratório de Vertebrados, Instituto de Ciências Biológicas, Universidade Federal do Rio Grande - FURG, Av. Itália, s/n, Km 08, Vila Carreiros, CEP 96203-900, Rio Grande, RS, Brasil

*e-mail: regnet_ruth@hotmail.com

Received: June 16, 2017 - Accepted: August 22, 2017 - Distributed: February 28, 2019

(With 1 figure)

In the past decades, a large number of researchers have mapped the causes responsible for the decline of several amphibian species, a known global phenomenon since the early 1990s (Wake, 1991). Although habitat loss and overutilization have been pinpointed as the main motivators of Amphibians declines (e.g. Stuart et al., 2004; Becker et al., 2007; Eigenbrod et al., 2008; Harper et al., 2008; Smith et al., 2009), others biological and anthropic factors have directly impacted amphibian communities (see Alford and Richards, 1999; Young et al., 2001; Hayes et al., 2010). In a local-regional perspective, factors such as the use of road salt, catastrophic events, fires, among others, are responsible for population declines. Herein, we described an episode of anuran deaths caused by eletric discharge in a temporary pond.

On 07 November 2016 at 8:30 a.m., we found a group of 15 dead mature frogs in a temporary pond located at Universidade Federal do Rio Grande (FURG), municipality of Rio Grande, state of Rio Grande do Sul, Brazil (-32.0754 S-52.1689, $7 \mathrm{~m}$ above sea level). All of them were found in a ca. $2 \mathrm{~m}$ radius from a lamppost which was flooded on its basis (Figure 1). We used a Minipa Et3110 Digital Clamp Multimeter to measure voltage and recorded a current of 34.8 volts in the water. The following species were recorded dead: Elachistocleis bicolor (GuérinMéneville, 1838) (2 males and 2 females), Leptodactylus latrans (Steffen, 1815) (1 male and 5 females), one male of Pseudopaludicola falcipes (Hensel, 1867), and one male of Rhinella arenarum (Hensel, 1867). A total of three individuals were note possible to identify to he species level. Snout-vent length among species ranged from $15.3 \mathrm{~mm}$ to $87.7 \mathrm{~mm}$. The number of deaths by electric discharge was underestimated, seeing as some individuals were consumed by native birds (RAR personal observation). Dead specimens were collected and deposited at the Herpetological Collection of FURG, collecting numbers 5258 to 5269 .

Our findings revealed anuran mortality caused by dissipated electricity in the water. Although this situation seems to be unusual, power grids installed in temporary pond sites may dissipate electricity through the water. Our concern regarding this subject is the synchronism between the formation of temporary ponds and anuran aggregation for reproduction. Such a confluence of events should be highlighted in our study area, since it is the preferred breeding habitat for most species (Loebmann, 2005). Additionally, this scenario may impact tadpoles that develop at that same pond.

Hayes et al., (2010) summarized causes responsible for amphibian declines and split them into three distinct levels. These causes may act isolated or combined, including vertical interactions between levels. Following Hayes' classification, our findings can be classified as Level 2 factors (factors contributing to death and failed recruitment), factor 'other mortality' (i.e. caused by incidental deaths in the current report). There are no previous studies reporting amphibian mortality caused by incidental electric discharge. This fatality emphasizes the consequences of
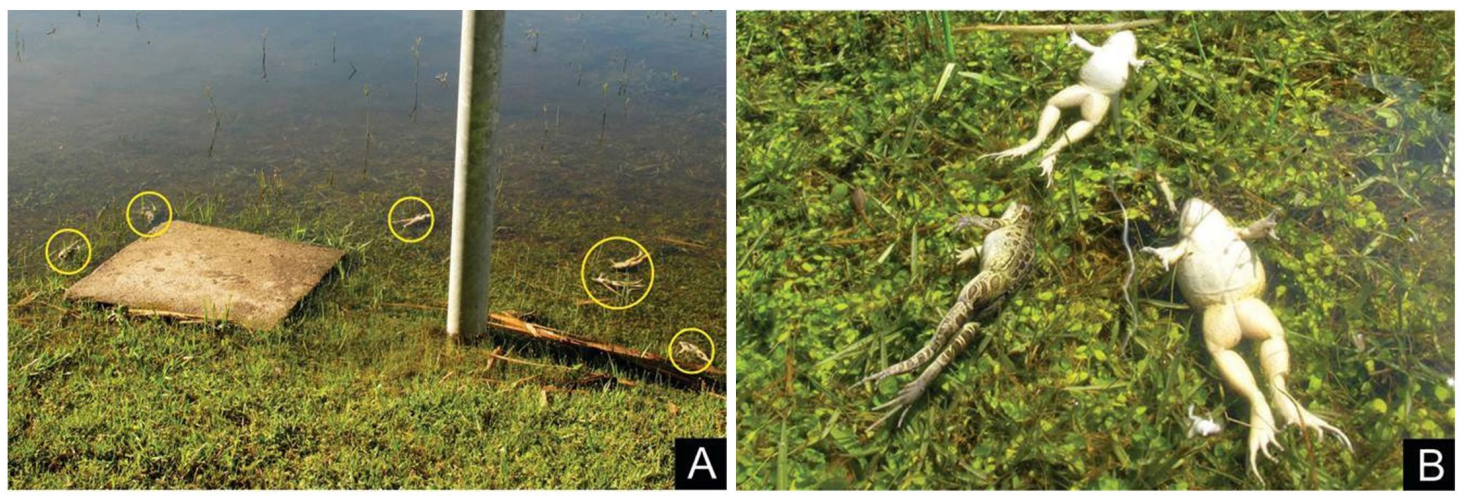

Figure 1. (A) Lamppost which was flooded on its basis with dead specimens highlighted in yellow circles; (B) Some of the dead individuals in closeup. Photograph by Ruth A. Regnet. 
the loss of natural habitat by amphibians and, therefore, reinforces the necessity to properly manage the natural dynamism of temporary lakes, protecting aquatic biota from anthropic impacts.

RAR thanks CAPES for providing the MSc. scholarship. Authors are grateful to employers from the electronic department of FURG, who helped measure electric currents at the pond.

\section{References}

ALFORD, R.S. and RICHARDS, S.J., 1999. Global amphibian declines: a problem in applied ecology. Annual Review of Ecology and Systematics, vol. 30, no. 1, pp. 133-165. http://dx.doi. org/10.1146/annurev.ecolsys.30.1.133.

BECKER, C.G., FONSECA, C.R., HADDAD, C.F.B., BATISTA, R.F. and PRADO, P.I., 2007. Habitat split and the global decline of amphibians. Science, vol. 318, no. 5857, pp. 1775-1777. http:// dx.doi.org/10.1126/science.1149374. PMid:18079402.

EIGENBROD, F., HECNAR, S.J. and FAHRIG, L., 2008. Accessible habitat: an improved measure of the effects of habitat loss and roads on wildlife populations. Landscape Ecology, vol. 23, no. 2, pp. 159-168. http://dx.doi.org/10.1007/s10980-007-9174-7.

HARPER, E.B., RITTENHOUSE, T.A.G. and SEMLITSCH, R.D., 2008. Demographic consequences of terrestrial habitat loss for pool-breeding amphibians: predicting extinction risks associated with inadequate size of buffer zones. Conservation Biology, vol. 22, no. 5, pp. 1205-1215. http://dx.doi.org/10.1111/j.15231739.2008.01015.x. PMid:18717698.
HAYES, T.B., FALSO, P., GALLIPEAU, S. and STICE, M., 2010. The cause of global amphibian declines: a developmental endocrinologist's perspective. The Journal of Experimental Biology, vol. 213, no. 6, pp. 921-933. http://dx.doi.org/10.1242/ jeb.040865. PMid:20190117.

LOEBMANN, D. 2005. Guia Ilustrado: os anfibios da região costeira do extremo sul do Brasil. Pelotas: União Sul-Americana de Estudos da Biodiversidade, $76 \mathrm{p}$.

SMITH, K.G., LIPS, K.R. and CHASE, J.M., 2009. Selecting for extinction: nonrandom disease-associated extinction homogenizes amphibian biotas. Ecology Letters, vol. 12, no. 10, pp. 10691078. http://dx.doi.org/10.1111/j.1461-0248.2009.01363.x. PMid:19694784.

STUART, S.N., CHANSON, J.S., COX, N.A., YOUNG, B.E., RODRIGUES, A.S.L., FISCHMAN, D.L. and WALLER, R.W., 2004. Status and trends of amphibian declines and extinctions worldwide. Science, vol. 306, no. 5702, pp. 1783-1786. http:// dx.doi.org/10.1126/science.1103538. PMid:15486254.

WAKE, D.B., 1991. Declining amphibian populations. Science, vol. 253, no. 5022, p. 860. http://dx.doi.org/10.1126/ science.253.5022.860. PMid:17751819.

YOUNG, B.E., LIPS, K.R., REASER, J.K., IBANEZ, R., SALAS, A.W., CEDENO, J.R., COLOMA, L.A., RON, S., LA MARCA, E., MEYER, J.R., MUNOZ, A., BOLANOS, F., CHAVES, G. and ROMO, D., 2001. Population declines and priorities for amphibian conservation in Latin America. Conservation Biology, vol. 15, no. 5, pp. 1213-1223. http://dx.doi.org/10.1046/j.15231739.2001.00218.x. 